\title{
Lymphokine activated killer cells from peripheral blood mononuclear cells of endometriosis of patients improve cytotoxicity to endometriosis cell culture
} \author{
Schiavon, ${ }^{3}$ Armand Bensussan ${ }^{3}$ \\ ${ }^{1}$ Doctoral Program Faculty of Medicine, University of Indonesia, Jakarta, Indonesia \\ ${ }^{2}$ Faculty of Medicine University of Indonesia, Jakarta, Indonesia \\ ${ }^{3}$ INSERM U976, Saint-Louis Hospital-Paris VII, Paris, France
}

Muharam Natadisastra, ${ }^{1}$ Arleni A. Bustami, ${ }^{2}$ Indra G. Mansur, ${ }^{2}$ Teuku Z. Jacoeb, ${ }^{2}$ Jerome Giustiniani, ${ }^{3}$ Valerie

\begin{abstract}
Abstrak
Latar belakang: Untuk menilai peningkatan imunitas selular terhadap biakan sel endometriosis dari sel LAK hasil perangsangan Sel Mononuklir Darah Tepi (SMDT) penderita endometriosis dengan IL-2.

Metode: Studi ini merupakan penelitian kuasi-eksperimental pra dan pasca-perlakuan dengan menggunakan pembanding (kontrol). Dilakukan pemeriksaan fenotip $\mathrm{CD}^{+} \mathrm{CD}^{+}, \mathrm{CD}^{+} \mathrm{CD}^{+}$dan $\mathrm{CD}^{2} 6^{+}$sel efektor dari SMDT endometriosis dan kontrol. Dilakukan pula uji sitotoksisititas SMDT penderita endometriosis dan kontrol terhadap lini-sel Daudi, K562, dan biakan sel endometriosis dengan menggunakan 51 Chromium pada teknik teraradioimun (radioimmunoassay, RIA)

Hasil: Pada pemeriksaan fenotip SMDT dari 10 pasien endometriosis dan 6 pasien kontrol pada sebelum dan sesudah perangsangan dengan IL-2 ditemukan bahwa sebelum perangsangan dengan IL-2 ditemukan $C D 3^{+} C D 4^{+}, C D 56$ pada kelompok endometriosis lebih rendah daripada kelompok kontrol $(p>0,05)$; fenotip $C D 3^{+} C D 8^{+}$pada kelompok endometriosis lebih tinggi daripada kelompok kontrol. Setelah perangsangan dengan $I L-2$ ditemukan $C D 3^{+} C D 8^{+}$, $C D 56^{+}$dari SMDT kelompok endometriosis lebih tinggi daripada sebelum perangsangan dengan IL-2 dan ditemukan perbedaan yang bermakna $(p<0,05)$. Pada uji sitotoksisitas ditemukan peningkatan bermakna $(p<0,05)$ sitotoksisitas sel efektor baik pada SMDT endometriosis maupun SMDT kontrol terhadap sasaran (target) lini-sel Daudi dan K562 setelah perangsangan IL-2. Sitotoksisitas sel efektor baik pada SMDT endometriosis maupun SMDT kontrol terhadap sasaran biakan sel endometriosis setelah perangsangan IL-2 tampak meningkat
\end{abstract}

Kesimpulan: Sel LAK hasil perangsangan SDMT penderita endometriosis dengan IL-2 meningkatkan imunitas selular terhadap biakan sel endometriosis. (Med J Indones 2011; 20:87-93 )

\begin{abstract}
Background: To assess the increased cellular immunity of Peripheral Blood Mononuclear Cells (PBMC) derived LAK cells from endometriosis patients towards endometriosis cell cultures after stimulation with IL-2.

Methods: This study is a quasi-experimental study of pre and post treatment using controls. Phenotype evaluation of $\mathrm{CD}^{+} \mathrm{CD}^{+}, \mathrm{CD}^{+}{ }^{+} \mathrm{CD} 8^{+}$and $\mathrm{CD} 56^{+}$effector cells of PBMC from endometriosis patients and controls was performed Cytotoxicity test of PBMC from endometriosis patients and control towards Daudi, K562 cell line and endometriosis cell cultures using 51Chromium release assay was also carried out.

Results: Phenotype evaluation of PBMC from endometriosis patients $(\mathrm{n}=10)$ and controls $(\mathrm{n}=6)$ were done prior to and after IL-2 stimulation. Before IL-2 stimulation, $\mathrm{CD}^{+} \mathrm{CD}^{+}, \mathrm{CD} 56^{+}$from endometriosis group $(\mathrm{n}=10)$ tend to be lower than control $(n=6)$ whereas $\mathrm{CD} 3^{+} \mathrm{CD} 8{ }^{+}$were higher in endometriosis group than controls. After IL-2 stimulation, $\mathrm{CD}^{+}$ $\mathrm{CD}^{+}, \mathrm{CD}^{2} 6^{+}$of PBMC from endometriosis group were significantly increased $(\mathrm{p}<0.05)$. Cytotoxicity test revealed a significant increase $(\mathrm{p}<0.05)$ in both PBMC's effector cells from endometriosis and control group towards target cells, Daudi, and K562 cell lines after IL-2 stimulation. PBMC's effector cells cytotoxicity from both endometriosis and control towards target endometriosis cell cultures were also elevated after IL-2 stimulation.
\end{abstract}

Conclusion: LAK cells derived IL-2 stimulated PBMC from endometriosis patients increased cellular immunity towards endometriosis cell cultures. (Med J Indones 2011; 20:87-93)

Key words: Daudi cell line, endometriosis, endometriosis cell cultures, K562 cell line, LAK cells, NK cells

Endometriosis is an endometrial-like benign disorder which grows outside the uterine cavity, and commonly triggers chronic inflammatory reaction..$^{1-3}$ Chronic pelvic pain, infertility, and menstrual disorders are among the most common symptoms related to endometriosis. Endometriosis associated internal genitalia adhesion is often ended up with hysterectomy. Recurrence rate after surgery and hormonal treatment is 33.3 to $40.3 \%$. Furthermore, endometriosis Correspondence email to: rmuharam@yahoo.com could disrupt women's productivity and is also related with a high cost treatment., ${ }^{2,3}$

Endometriosis is estimated to affect 10 to $15 \%$ women in reproductive age. It is estimated that about 5-21\% of patients with endometriosis are hospitalized due to pelvic pain. ${ }^{2}$ In 2005 , around 170 million or $10 \%$ of total world population of women in reproductive age were associated with endometriosis while in 
Indonesia, an estimation of 6.1 million women were with this disorder., ${ }^{4,5}$ Since first described by Austrian Karl Freiherr von Rokitansky (1860), various theories have been proposed to explain the pathogenesis of endometriosis, including involvement of immune system. ${ }^{4,6-8}$ Immune related theory in endometriosis is probably most attractive when by connected with other theories thus might be potential to develop a strategy in endometriosis therapy.

The presence of immunologicaldefects in endometriosis, especially impairment of natural killer (NK) cell function and activity has been widely described. ${ }^{9}$ Decreased activity of NK cells is a qualitative defect thus not caused by lack of NK cell numbers. ${ }^{10}$ Decrease in NK cell activity resulted in disruption of endometrial clearance including those in the reversed flow into the peritoneal cavity. ${ }^{11,12}$ Decreased activity of NK cells in peripheral blood mononuclear cells (PBMC) has also been described in patients with endometriosis. ${ }^{13,14}$

NK cells cytotoxicity can be enhanced after stimulation of interleukin (IL)-2 into lymphokine activated killer (LAK) cells. LAK cells are leukocytes stimulated tumor killer cells which are associated with non restricted major histocompatibility complex (MHC) antigens. ${ }^{15}$ The cytotoxic capacity of LAK cells can be determined by using Daudi, K562 cell lines, and endometrial cell culture. Destruction of K562 cell line would only be caused by NK cells while Daudi cell line is a target of cytotoxic T and LAK cells can destruct both of two cell lines. ${ }^{9,16}$

Oosterlynck, et $\mathrm{al}^{17}$ found an elevation of PBMC's cytotoxic activity after stimulation with IL-2 for three days on endometrial cultured and uncultured cells, taken from the uterus of endometriosis patients controls and non endometriosis controls. To our knowledge, there is no endometriosis study using IL-2 stimulated LAK cells from PBMC's endometriosis patients with IL-2 against endometriosis cell cultures, this study is different from study done by Oosterlynck, et.al. who used target cells endometrial carcinoma (AN3CA and RL95) and endometrial cells. ${ }^{16,18}$

\section{METHODS}

This study is a pre and post-treatment quasi experiment versus controls, assessing the role of LAK cells from IL-2 stimulated PBMC of endometriosis patients on endometriosis cell cultures. Samples were collected from PBMC of endometriosi and non endometriosis patients (controls).

Samples for this study were taken from dr. Cipto Mangunkusumo General Hospital Jakarta, and Fatmawati Hospital Jakarta, from November 2009 to June 2010.
Samples were processed and assessed in Makmal Integrated Immunoendocrinology Faculty of Medicine, University of Indonesia (MTIE-FMUI) and the INSERM U976 Saint-Louis Hospital, Paris VII, Paris, France. Approval for the study was obtained from the Institutional Review Board of the Faculty of Medicine, University of Indonesia.

\section{Subjects and samples}

The subjects of this study were women undergoing laparoscopy for endometriosis treatment $(n=10)$ and control $(n=6)$ in the Division of Reproductive Immunoendocrinology, Department of Obstetrics and Gynecology, dr. Cipto Mangunkusumo Hospital Jakarta, and Fatmawati Hospital Jakarta. None of the patients received any hormonal treatment during the 3 months prior to the intervention. Endometriosis scoring was determined according to the revised American Fertility Society Classification. Endometriosis was diagnosed as class III $(n=2)$ and class IV $(n=8)$. The diagnosis was further confirmed by histopathology examination. Endometriosis cells were obtained from endometriosis cysts taken from each patient after laparoscopy.

Venous blood samples were taken from healthy volunteers $(n=6)$ and endometriosis patients $(n=10)$ for evaluation of NK cells, cytotoxic T cells, PBMC and LAK cells. Blood samples were collected into heparinized tubes and delivered to the laboratory. All subjects signed a consent form approved by the FMUI. PBMC were isolated by Ficoll-Hypaque gradient centrifugation. PBMC were then recovered, washed in phosphate buffered saline (PBS), counted, and assessed for viability in a trypan blue dye $(0.2 \%(\mathrm{v} / \mathrm{v})$ in PBS), and promptly used for flow cytometry and Chromium Release Assay (CRA).

\section{Cell targets}

K562, a human chronic myelogenous leukemia cell line, was cultured in RPMI 1640 medium supplemented with $10 \%(\mathrm{v} / \mathrm{v})$ heat-inactivated fetal calf serum (FCS), $2 \mathrm{mM}$ L-glutamine, $100 \mathrm{U} / \mathrm{mL}$ penicillin, and $100 \mu \mathrm{g} /$ $\mathrm{mL}$ streptomycin (complete medium, $\mathrm{CM}$ ) at $37^{\circ} \mathrm{C}$, $5 \% \mathrm{CO}_{2}$. Daudi, a space human lymphoma cell line, and primary endometriosis culture were cultured in culture medium and used as targets for NK cell, cytotoxic T cell, PBMC and LAK cell assays. Target cells were harvested on day4, washed in PBS and counted in a trypan blue dye prior to examination. K562 and Daudi cell lines were kindly provided by INSERM.

\section{LAK cell generation}

PBMC were cultured in the complete medium (CM) describedabove. The CMwas additionally supplemented with $100 \mathrm{IU} / \mathrm{mL}$ of recombinant human IL-2 (kindly 
provided by INSERM). Cells were cultured in triplicate in a 24 wells plate at $37^{\circ} \mathrm{C}, 5 \% \mathrm{CO}_{2}$ for 4 days. On day 4 , LAK cells were harvested, counted, and evaluated for cytotoxic activity towards Daudi, K562 cell lines and endometriosis cells.

\section{${ }^{51}$ Cr-release assay}

$\mathrm{K}-562$, Daudi cell lines and endometriosis cells were labeled with $100 \mu \mathrm{Ci}$ of ${ }^{51} \mathrm{Cr} \mathrm{mCi} / \mathrm{mg}$ (Perkin Elmer, Billerica, MA $400-1200 \mathrm{Ci}$ ) for $1 \mathrm{~h}$ at $37^{\circ} \mathrm{C}$ and used as target cells. The labeled cells were washed twice, resuspended in complete medium, and counted for the viable cells. Cells were co-incubated at a ratio 1:20; 1:5 between target to effector (T:E) cells. NK-cell, T-cell, PBMC and LAK-cell assays were done with $5 \times 10^{3}$ labeled target cells per well in triplicate using 96-wells V-bottom microtiter plates.

The final volume of culture medium with $10 \%$ FCS was $200 \mu \mathrm{l}$ in each well. After $4 \mathrm{~h}$ of incubation, $100 \mu \mathrm{l}$ of medium was removed from each well in a $\gamma$ counter to determine ${ }^{51} \mathrm{Cr}$ release. Radioactivity was measured by Trilux Micro Beta Automatic Gamma Counter. This procedur was performed at INSERM U976 Saint-Louis Hospital, Paris VII, Paris, France.

The percentage of cytotoxic activity was calculated using the formula:

$\%$ specific lysis $=($ sample $\mathrm{cpm}-$ spontaneous $\mathrm{cpm}) /$ (maximal cpm-spontaneous cpm) $\times 100 \%$.

\section{Immunoflurescence Assay}

In parallel to measurement of cytotoxicity, phenotypic analyses were performed with Ficoll/hypaque peripheral blood leukocyte gated on lymphocytes. For immunofluorescence experiment, cells were simultaneously incubated for $30 \mathrm{~min}$ with a PE-conjugated $\mathrm{mAB}$, PCy5-conjugated mAB and FITC-labeled BY55 mAB. Indirect immunofluorescence assay was perfomed using a PE-conjugated goat anti mouse IgM from Beckman Coulter. Analysis was which performed on a FACScan microfluorometer (Beckman Coulter FC50) after compensation among PE, PCy5 and FITC. This procedur was performed at INSERM U976 Saint-Louis Hospital, Paris VII, Paris, France.

\section{Data analysis}

Data was recorded on a special form and analyzed statistically using SPSS 12.0. Descriptive data was displayed to see the phenotype characteristics of $\mathrm{CD}^{+} \mathrm{CD}^{+}, \mathrm{CD}^{+} \mathrm{CD}^{+}, \mathrm{CD} 56$ and cytotoxicity of $\mathrm{NK}$ cells, cytotoxic $\mathrm{T}$ cells, and PBMC's LAK cells from endometriosis patients and controls towards Daudi, K562 cell lines and endometriosis cell cultures. Normality test was performed using Kolmogorov-Smirnov, univariate analysis and followed by bivariate analysis. Normally distributed data was tested using unpaired t-test. Pre-and post-treatment data was analyzed using a parametric test (pair test). On the contrary, abnormal data pattern was analyzed using Mann-Whitney test on unpaired groups and Wilcoxon test for pre-and post-treatment pairs.

\section{RESULTS}

In this study, samples consisted of PBMC from endometriosis patients $(n=10 ; 2$ moderate and 8 severe stage), and control $(n=6)$. Before stimulation with IL-2 on PBMC from endometriosis and controls, $\mathrm{CD}^{+} \mathrm{CD}^{+}$ (helper $\mathrm{T}$ cells), $\mathrm{CD}^{+} 6^{+}$(NK cells) phenotype in endometriosis group was lower than the control group although there was no significant difference. Furthermore, the $\mathrm{CD}^{+} \mathrm{CD}^{+}$(cytotoxic $\mathrm{T}$ cells) of endometriosis group was higher than the control group without any significant difference. It appears that the ratio of $\mathrm{CD}^{+}$(helper T cells) to $\mathrm{CD}^{+}$(cytotoxic T cells) in the endometriosis group is less than one (Table 1).

Cytotoxicity test before IL-2 stimulation revealed that cytotoxic T cells in endometriosis group were lower than the ineffective control group. Moreover, the NK cells in endometriosis group were significantly lower than those in control group. The cytotoxicity of PBMC from endometriosis group was also lower compared to the control group. It appears that even though the toxicity was lower than control, PBMC from the endometriosis group could react effectively towards endometrial cell cultures before IL-2 stimulation (Table 2).

Table 1. Characteristics of controlled PBMC and endometriosis phenotype

\begin{tabular}{|c|c|c|c|c|c|c|c|}
\hline \multirow{2}{*}{ Phenotype } & \multicolumn{3}{|r|}{ Endometriosis } & \multicolumn{3}{|r|}{ Controlled } & \multirow{2}{*}{$\mathrm{p}$} \\
\hline & $\mathrm{n}$ & & Median (min-max) & $\mathrm{n}$ & & Median (min-max) & \\
\hline $\mathrm{CD}^{+}$ & 10 & 74,4 & $(43,50-92,01)$ & 6 & 72,9 & $(70,56-84,00)$ & 0,871 \\
\hline $\mathrm{CD}^{+} \mathrm{CD}^{+}$ & 10 & 27,8 & $(22,59-58,81)$ & 6 & 42,8 & $(29,55-58,82)$ & 0,104 \\
\hline $\mathrm{CD}^{+} \mathrm{CD}^{+}$ & 10 & 31,1 & $(14,50-46,14)$ & 6 & 26,4 & $(20,25-41,09)$ & 0,745 \\
\hline $\mathrm{CD} 6^{+}$ & 10 & 11,7 & $(4,50-35,44)$ & 6 & 12,4 & $(7,78-29,43)$ & 0,588 \\
\hline
\end{tabular}

Mann Whitney test; phenotype unit (\%); $\mathrm{CD}^{+}\left(\mathrm{T}\right.$ cells); $\mathrm{CD}^{+} \mathrm{CD}^{+}$(helper T cells); $\mathrm{CD} 3^{+} \mathrm{CD}^{+}$(cytotoxic $\mathrm{T}$ cells); $\mathrm{CD} 56^{+}(\mathrm{NK}$ cell); significant if $\mathrm{p}<0,05$ 
The phenotypes of $\mathrm{CD}^{+} \mathrm{CD}^{+}, \mathrm{CD}^{+} \mathrm{CD} 8^{+}$and $\mathrm{CD} 56^{+}$ from both endometriosis and control group were increased after stimulation with IL-2. Elevation of $\mathrm{CD}^{+}{ }^{+} \mathrm{CD} 4^{+}$(helper $\mathrm{T}$ cells) and $\mathrm{CD} 3^{+} \mathrm{CD} 8^{+}(\mathrm{T}$ cytotoxic cells) after stimulation with IL-2 were significantly higher ( $p=0.005$ and $p=0.007$, respectively) than before treatment. It has also been found that the ratio of $\mathrm{CD}^{+}$(helper $\mathrm{T}$ cells) to $\mathrm{CD} 8^{+}$( $\mathrm{T}$ cytotoxic cells) in PBMC from endometriosis group was greater than 1after stimulation with IL-2 (Table 3, Figure 1, Figure 2, and Figure 3).
The cytotoxicity of LAK cells from endometriosis group towards Daudi, K562cell lines, and endometriosis cell cultures was increased after IL-2 stimulation. It seems that cytotoxic $T$ cells from endometriosis group could response effectively towards Daudi cell line after IL-2 stimulation by activation into LAK cells. Likewise, cytotoxic $T$ cells in control group could also react towards Daudi cell line after IL-2 stimulation with higher efficiency than the endometriosis group. Furthermore, NK cells in endometriosis group could respond more potently towards K562 cell line after IL-2 stimulation. However, its toxicity was lower than control group.

Table 2. Cytotoxicity test with 51Cr 1:20 and 51Cr 1:5 calibration on PBMC in endometriosis and control groups before to stimulation with IL-2 on Daudi, K562 cell lines and endometriosis cell cultures

\begin{tabular}{|c|c|c|c|c|c|c|c|c|}
\hline \multirow{2}{*}{ Target cell } & \multirow{2}{*}{${ }^{51} \mathrm{Cr}$} & \multicolumn{3}{|c|}{ Endometriosis } & \multicolumn{3}{|c|}{ Control } & \multirow[b]{2}{*}{$p$} \\
\hline & & $\mathrm{n}$ & & $\operatorname{dian}(\min -\max )$ & $\mathrm{n}$ & & dian (min-max) & \\
\hline \multirow[t]{2}{*}{ Daudi cell line } & $1: 20$ & 10 & 2.4 & $(0.90-3.90)$ & 5 & 6.0 & $(1.80-9.30)$ & 0.125 \\
\hline & $1: 5$ & 10 & 1.7 & $(0.10-3.50)$ & 5 & 2.5 & $(0.60-5.60)$ & 0.297 \\
\hline \multirow[t]{2}{*}{ K562 cell line } & $1: 20$ & 10 & 3.4 & $(0.50-8.20)$ & 5 & 24.1 & $(1.30-38.20)$ & $0.050^{*}$ \\
\hline & $1: 5$ & 10 & 2.9 & $(0.90-7.50)$ & 5 & 9.7 & $(0.80-18.30)$ & 0.066 \\
\hline \multirow[t]{2}{*}{ Endometriosis cells } & $1: 20$ & 6 & 11.8 & $(9.20-28.00)$ & 4 & 21.7 & $(13.50-28,30)$ & 0.136 \\
\hline & $1: 5$ & 6 & 9.1 & $(0.00-22.50)$ & 4 & 17.4 & $(12.10-22.00)$ & 0.286 \\
\hline
\end{tabular}

Mann Whitney test; Cytotoxicity test in $\%$; cytotoxiticity value is effective if more than $10 \%$, and ineffective if less than $10 \%$ ); significant if $\mathrm{p}<0,05$; PBMC $=$ peripheral blood mononuclear cell

Table 3. PBMC phenotype characteristic groups before and after stimulation with IL-2

\begin{tabular}{|c|c|c|c|c|c|c|}
\hline \multirow{2}{*}{$\mathrm{n}$} & \multirow{2}{*}{ Phenotype } & \multicolumn{2}{|c|}{ Before stimulation with IL-2 } & \multicolumn{2}{|r|}{ After stimulation with IL-2 } & \multirow{2}{*}{$p$} \\
\hline & & & Median (min-max) & & Median (min-max) & \\
\hline \multicolumn{7}{|c|}{ Control group: } \\
\hline 6 & $\mathrm{CD}^{+}$ & 72.9 & $(70.56-84)$ & 73.1 & $(63.62-88.61)$ & 0,753 \\
\hline 6 & $\mathrm{CD}^{+} \mathrm{CD}^{+}$ & 42.8 & $(29.55-58,82)$ & 62.6 & $(33.4-70.26)$ & $0.028^{*}$ \\
\hline 6 & $\mathrm{CD}^{+} \mathrm{CD}^{+}$ & 26.4 & $(20.25-41.09)$ & 27.8 & $(13.77-40.82)$ & 0.917 \\
\hline 6 & $\mathrm{CD}_{5} 6^{+}$ & 12.4 & $(7.78-29.43)$ & 15.1 & $(4.88-33.48)$ & 0,173 \\
\hline \multicolumn{7}{|c|}{ Endometriosis group: } \\
\hline 10 & $\mathrm{CD}^{+}$ & 74.4 & $(43.50-92.01)$ & 81.4 & $(70.78-96.63)$ & $0.007 *$ \\
\hline 10 & $\mathrm{CD}^{+} \mathrm{CD}^{+}$ & 27.8 & $(22.59-58.81)$ & 48,5 & $(29.14-65.78)$ & $0.005^{*}$ \\
\hline 10 & $\mathrm{CD}^{+} \mathrm{CD}^{+}$ & 31.1 & $(14.50-46.14)$ & 39,3 & $(27.28-59.63)$ & $0.007 *$ \\
\hline 10 & $\mathrm{CD} 6^{+}$ & 11.7 & $(4.50-35.44)$ & 15,4 & $(7.04-42.20)$ & $0.007 *$ \\
\hline
\end{tabular}

Wilcoxon test; phenotype unit (\%); $\mathrm{CD}^{+}\left(\mathrm{T}\right.$ cells); $\mathrm{CD}^{+} \mathrm{CD}^{+}$(helper T cells); $\mathrm{CD}^{+} \mathrm{CD}^{+}$(cytotoxic T cells); $\mathrm{CD} 56^{+}(\mathrm{NK}$ cells); significant if $\mathrm{p}<0,05$

Table 4. Cytotoxicity test with 51Cr 1:20 and 51Cr 1:5 calibration in PBMC endometriosis group before and after stimulation with IL-2 against Daudi line-cells, K562 line-cells, and cultured endometriosis cell

\begin{tabular}{|c|c|c|c|c|c|c|c|c|}
\hline \multirow{2}{*}{ Target cell } & \multirow{2}{*}{${ }^{51} \mathrm{Cr}$} & \multicolumn{3}{|c|}{ Before stimulation with IL-2 } & \multicolumn{3}{|c|}{ After stimulation with IL-2 } & \multirow{2}{*}{$p$} \\
\hline & & $\bar{n}$ & & Median (min-max) & $\mathrm{n}$ & & edian (min-max) & \\
\hline \multirow[t]{2}{*}{ Daudi line-cell } & $1: 20$ & 10 & 2.4 & $(0.90-3.90)$ & 10 & 20.9 & $(5.60-33.50)$ & $0.005^{*}$ \\
\hline & $1: 5$ & 10 & 1.7 & $(0.10-3.50)$ & 9 & 8.8 & $(2.60-24.10)$ & $0.011 *$ \\
\hline \multirow[t]{2}{*}{ K562 line-cell } & $1: 20$ & 10 & 3.4 & $(0.50-8.20)$ & 10 & 25.3 & $(3.60-38.60)$ & $0.005^{*}$ \\
\hline & $1: 5$ & 10 & 2.9 & $(0.90-7.50)$ & 10 & 12.1 & $(1.80-28.50)$ & $0,005^{*}$ \\
\hline \multirow[t]{2}{*}{ Endometriosis cell } & $1: 20$ & 6 & 11.8 & $(9.20-28.00)$ & 6 & 16.7 & $(9.60-28.70)$ & 0.345 \\
\hline & $1: 5$ & 6 & 9.1 & $(0.00-22.50)$ & 6 & 13.1 & $(1.91-18.82)$ & 0.917 \\
\hline
\end{tabular}

Wilcoxon test; Toxiticity value in $\%$; Cytotoxicity value if effective if more than $10 \%$, and ineffective if less than $10 \%$ ); Significant if $\mathrm{p}<0,05$; PBMC $=$ peripheral blood mononuclear cell 


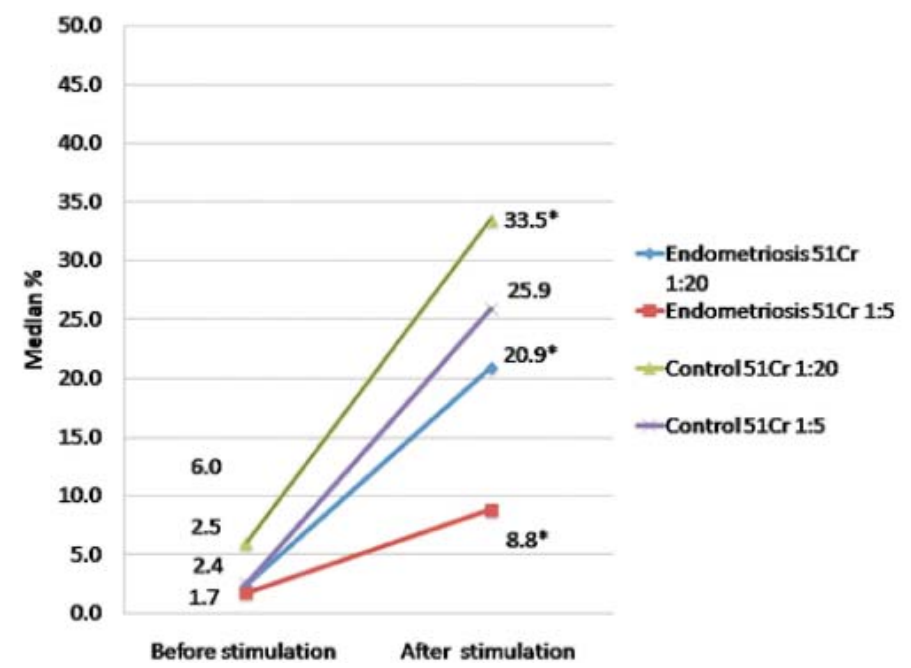

Figure 1. Endometriosis and control group before and after IL-2 stimulation towards Daudi cell line with calibration of ${ }^{51} \mathrm{Cr} 1: 20$ dan ${ }^{51} \mathrm{Cr}$ $1: 5$

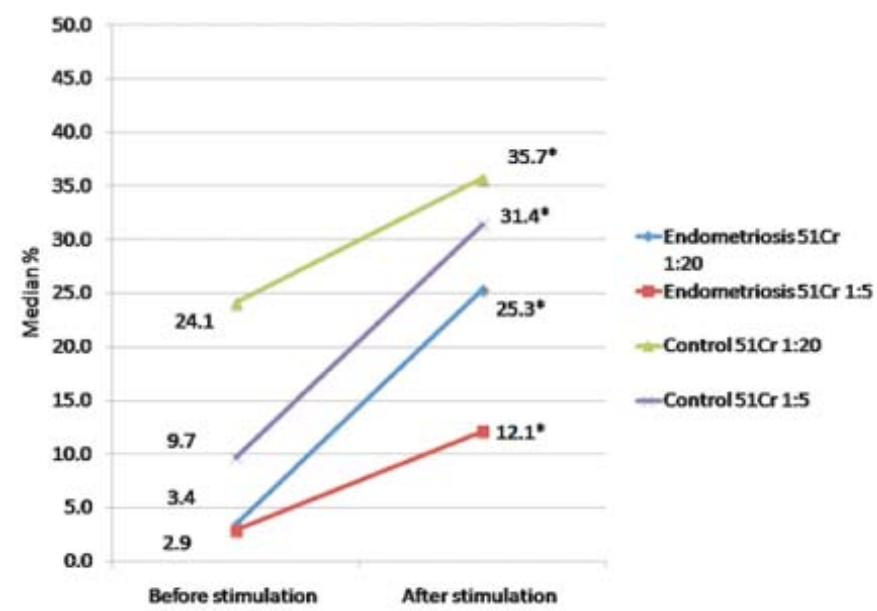

Figure 2. PBMC cytotoxicity and endometriosis LAK cells group and the control before and after stimulation with IL-2 towards K562 cells-line with calibration of $51 \mathrm{Cr} 1: 20$ and $51 \mathrm{Cr}$ 1:5.

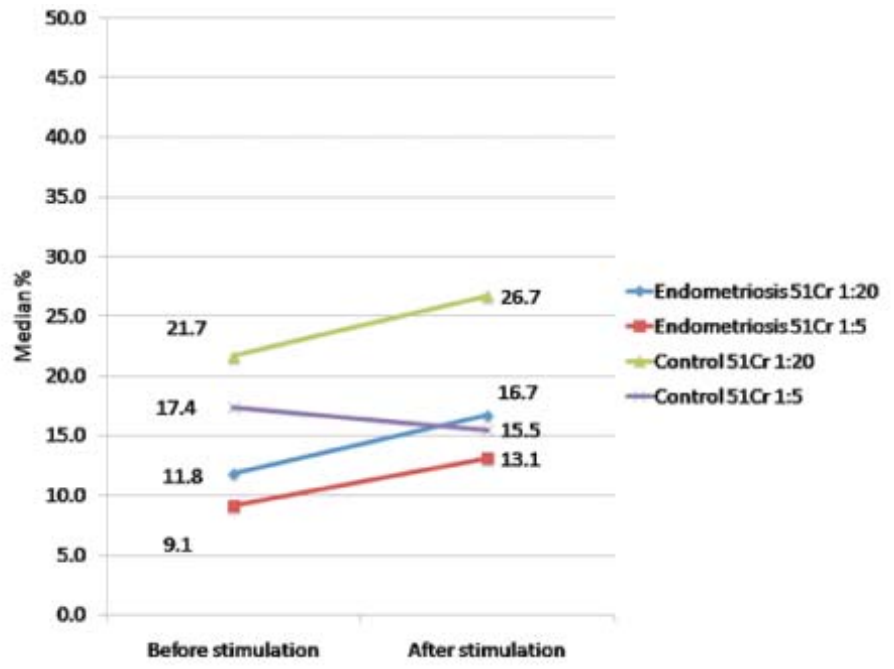

Figure 3. Cytotoxicity of PBMC and LAK cells in endometriosis group before and after IL-2 stimulation towards endometriosis cell cultures labeled with calibration of ${ }^{51} \mathrm{Cr}$ 1:20 and ${ }^{51} \mathrm{Cr}$ 1:5. 


\section{DISCUSSION}

Endometriosis is an endometrial-like benign disorder which grows outside the uterine cavity, and could trigger chronic inflammatory reaction. ${ }^{1-4}$ Theories have been proposed to explain the pathogenesis of endometriosis. Immune related theory was one of the most attractive theories which could interrelate with other theories. Thus, immune factors may play an important role to prevent and overcome endometriosis regardless its pathogenesis. Endometriosis associated immunological defect, particularly in NK cells function and activity, has been widely reported. In this study we demonstrate a defect in PBMC's NK cells from endometriosis group before IL-2 stimulation towards K562 cell line. Impairment of NK cells function from endometriosis group was also supported by the fact that cytotoxicity of LAK cells after IL-2 stimulation was lower than control group.

Impairment of NK cells function could be repaired by stimulating PBMC from endometriosis patients with IL-2 to activate them into LAK cells. Study by Rousse $^{19}$ showed an increased proliferation of $\mathrm{CD}^{+}$ after IL-2 stimulation related to the formation of LAK cells. Furthermore, Oosterlynck et $\mathrm{al}^{17}$ did not find any significant difference between the endometriosis $(n=13)$ and control group $(\mathrm{n}=5)$ without IL-2 stimulation.

Difference in immune response is also affected by genetic factors. Hsieh et $\mathrm{al}^{20}$ reported an association of homozygous polymorphism of IL-2 receptor beta (IL-2Rbeta)-627*C with endometriosis. Moreover, Kitawaki et $\mathrm{al}^{21}$ demonstrated that the genotype of killer cells immunoglobulin-like receptors (KIRs) is correlated with susceptibility towards endometriosis. Our study found a significant increase of the phenotype $\mathrm{CD}^{+} \mathrm{CD}^{+}$(helper $\mathrm{T}$ cells), $\mathrm{CD}^{+} 6^{+}$(NK cells) after IL-2 stimulation in PBMC of endometriosis group. There was also elevation in LAK cell cytotoxicity from endometriosis group towards Daudi, K562 cell lines and endometriosis cell cultures after IL-2 stimulation. From this study, we assume that IL-2 can stimulate activation of PBMC into LAK cells which are more potent in cytotoxicity and not associated with $\mathrm{MHC}$ antigens. ${ }^{15}$

In this study, the increase of LAK cells cytotoxicity from endometriosis group is lower than control. Szyllo et $\mathrm{al}^{22}$ reported that IL-2 concentration in PBMC from endometriosis patients was higher $(8.3 \pm 7.13)$ than control $(2.8 \pm 1.28)$ after stimulation with phytohemagglutinin (PHA). Oosterlynck et $\mathrm{al}^{17}$ stated that there is no intrinsic abnormality found in lymphocyte cells of endometriosis patients since they are still capable to respond after IL-2 stimulation. Tsudo et $\mathrm{al}^{23}$ described an important role of $\mathrm{p} 75$ peptide as receptor of IL-2 on large granular lymphocytes in the activation of these cells into LAK cells. Disruption in affinity between p75 and IL-2 would cause a decrease in proliferation response after IL-2 stimulation in patients with leukemia. Therefore, the role of $\mathrm{p} 75$ in pathogenesis of endometriosis should be further elaborated.

In conclusion, defect of cellular immunity in endometriosis could be repaired by stimulating PBMC from endometriosis patients with IL-2 into LAK cells. Activation of PBMC into LAK cells after IL-2 stimulation in endometriosis group resulted in increased cellular immunity towards endometriosis cell cultures.

\section{Acknowledgments}

We thank the staffs of INSERM U976 Saint Louis Hospital-Paris VII, for their support in conducting this research. We also thank MTIE FMUI and Division of Reproductive Immunoendocrinology FMUI, especially to Professors Endy M. Moegni, Ali Baziad, Soetarti Eko Prasetyaningsih, Eva, Nilda, and Neneng.

\section{REFERENCES}

1. Haney AF. Etiology and histogenesis of endometriosis. Prog Clin Biol Res. 1990;323:1-14.

2. Jacoeb TZ. Faktor imunoendokrinologis dan seluler lingkungan mikro zalir peritoneal pada infertilitas idiopatik wanita. [disertasi]. Jakarta: Universitas Indonesia; 1990.

3. Missmer SA, Cramer DW. Epidemiology of endometriosis. In: Olive DL, editor. Endometriosis in clinical practice. London: Taylor \& Francis; 2005. p. 49-60.

4. Olive DL, Schwartz LB. Endometriosis. N Engl J Med. 1993;328(24):1759-69.

5. Oepomo TD. Peran interleukin- 6 serta interleukin- 8 dalam zalir peritoneal pada infertilitas disertai endometriosis dalam proses apoptosis sel granulosa ovarii yang patologis (suatu pendekatan imunopatologi). Maj Obstet Ginekol Indones. 2005;16:26.

6. Witz CA, Allsup KT, Montoya-Rodriguez IA, Vaughan SL, Centonze VE, Schenken RS. Pathogenesis of endometriosis-current research. Hum Fertil (Camb). 2003;6(1):34-40.

7. Bulun SE, Fang Z, Imir G, Gurates B, Tamura M, Yilmaz B, et al. Aromatase and endometriosis. Semin Reprod Med. 2004;22(1):45-50.

8. Kitawaki J, Kado N, Ishihara H, Koshiba H, Kitaoka Y, Honjo H. Endometriosis: the pathophysiology as an estrogen-dependent disease. J Steroid Biochem Mol Biol. 2002;83(1-5):149-55.

9. Lebovic DI, Mueller MD, Taylor RN. Immunobiology of endometriosis. Fertil Steril. 2001;75(1):1-10.

10. Gagne D, Rivard M, Page M, Lepine M, Platon C, Shazand $\mathrm{K}$, et al. Development of a nonsurgical diagnostic tool for endometriosis based on the detection of endometrial leukocyte subsets and serum CA-125 levels. Fertil Steril. 2003;80(4):876-85.

11. Claus M, Greil J, Watzl C. Comprehensive analysis of NK cell function in whole blood samples. J Immunol Methods. 2009;341:154-64.

12. Wu MY, Yang JH, Chao KH, Hwang JL, Yang YS, Ho $\mathrm{HN}$. Increase in the expression of killer cell inhibitory 
receptors on peritoneal natural killer cells in women with endometriosis. Fertil Steril. 2000;74(6):1187-91.

13. D'Hooghe TM. Clinical relevance of the baboon as a model for the study of endometriosis. Fertil Steril. 1997;68(4):613-25.

14. Farag SS, Caligiuri MA. Human natural killer cell development and biology. Blood Reviews. 2006;20:123-37.

15. Matsubara K, Nagamatsu T, Fuji T, Kozuma S, Taketani Y. Lymphokine-activated killer cells induced from decidual lymphocytes reduce the angiogenic activity of trophoblasts by enhancing the release of soluble fms-like tyrosine kinase-1 from trophoblasts: An implication for the pathophysiology of preeclampsia. J Reprod Immunol. 2005;68:27-37.

16. Lucidi RS, Witz CA, Chrisco M, Binkley PA, Shain SA, Schenken RS. Anovel in vitro model of the early endometriotic lesion demonstrates that attachment of endometrial cells to mesothelial cells is dependent on the source of endometrial cells. Fertil Steril. 2005;84(1):16-21.

17. Oosterlynck DJ, Lacquet FA, Waer M, Koninckx PR. Lymphokine-activated killer activity in women with endometriosis. Gynecol Obstet Invest. 1994;37(3):185-90.

18. Oner Ozdemira SS. Combinational IL-2/IL-15 induction does not further enhance IL-15-induced lymphokine-activated killer cell cytotoxicity against human leukemia/lymphoma cells. Clin Immunol. 2005;115:240-9.
19. Roussel E, Gerrard JM, Greenberg AH. Long-term cultures of human peripheral blood lymphocytes with recombinant human interleukin-2 generate a population of virtually pure CD3+CD16-CD56- large granular lymphocyte LAK cells. Clin exp Immunol. 1990;82:416-21.

20. Hsieh YY, Chang CC, Tsai FJ, Hsu CM, Lin CC, Tsai $\mathrm{CH}$. Interleukin-2 receptor beta (IL-2R beta) $-627 * \mathrm{C}$ homozygote but not IL-12R beta 1 codon 378 or IL-18 105 polymorphism is associated with higher susceptibility to endometriosis. Fertil Steril. 2005;84(2):510-2.

21. Kitawaki J, Obayashi H, Kado N, Ishihara H, Koshiba H, Maruya E, et al. Association of HLA class I and class II alleles with susceptibility to endometriosis. Hum Immunol. 2002;63(11):1033-8

22. Szyllo K, Tchorzewski H, Banasik M, Glowacka E, Lewkowicz $\mathrm{P}$, Kamer-Bartosinska A. The involvement of T lymphocytes in the pathogenesis of endometriotic tissues overgrowth in women with endometriosis. Mediators Inflamm. 2003;12(3):131-8.

23. Tsudo M, Goldman CK, Bongiovanni KF, Chan WC, Winton EF, Yagita M, et al. The p75 peptide is the receptor for interleukin 2 expressed on large granular lymphocytes and is responsible for the interleukin 2 activation of these cells. Proc Natl Acad Sci U S A. 1987;84(15):5394-8. 